\title{
Association of DRD2 (rs 1799732), ANKK1 (rs1800497), DAT (rs28363170), DRD4 (exon 3 - VNTR) gene polymorphisms in the context of relapses in therapy.
}

\author{
Jolanta Chmielowiec ${ }^{1}$ ABCDEF, https://orcid.org/0000-0003-3285-5313, \\ Agnieszka Boroń ${ }^{2}$ ABCDEF, https://orcid.org/0000-0003-3574-5726
}

\begin{abstract}
${ }^{1}$ Department of Hygiene and Epidemiology, Collegium Medicum, University of Zielona Góra, Poland ${ }^{2}$ Department of Clinical and Molecular Biochemistry, Pomeranian Medical University, Szczecin, Poland
\end{abstract}

\begin{abstract}
Introduction: Disorders in the field of reward system neurotransmission are mentioned as one of the most important causes of addiction. Genetic variation is assigned a special role. The literature on the subject mentions primarily the genes of dopamine neurotransmission: DAT (dopamine transporter), DRD2 (dopamine receptor D2), DRD4 (dopamine receptor D4). However, so far there are few literature reports on these genes in the context of innovators in addiction therapy.

The aim: Analysis of the relationship between the variability of specific polymorphisms in the DRD2 (rs1799732), ANKK1 (rs1800497), DAT (rs28363170), DRD4 (exon 3 - VNTR) genes with the occurrence of relapses in people addicted to psychoactive substances.

Material and methods: The research was carried out on a group of 301 people addicted to psychoactive substances staying in an addiction therapy center in Lubuskie and Zachodniopomorskie voivodships in Poland. The control group consisted of 301 people with no diagnosed addiction to psychoactive substances nor mental disorders. The study of polymorphisms DRD2 (rs 1799732), ANKK1 (rs1800497) was performed by real-time PCR method; whereas DAT (rs28363170), DRD4 (exon 3 - VNTR) was genotyped by PCR and the amplified products were visualized using ethidium bromide stained gel electrophoresis ( $3 \%$ agarose) and UV photography.

Results: This study showed that in addicts genotype frequencies of the VNTR polymorphism in the third exon of human DRD4 were as follow: S/L in 33.55\%, S/S - 63.12\% and L/L 3.32\%; while in the control group S/L - 32.56\%, S/S - 58.8 \% and L/L $8.6 \%(\chi 2=7.617, \mathrm{p}=0.022)$. Significant differences in the frequency of $D R D 2$ gene polymorphism rs1799732 were observed (frequency of alleles; $\chi 2=5.48, \mathrm{p}=0.0192$ ) and DRD4 VNTR polymorphism ( $\chi 2=7.687, \mathrm{p}=0.021$ ) between the addicted to psychoactive substances who have a one-time stay in an inpatient treatment center and the control group.
\end{abstract}

Keywords: gene, relapses of addiction, addiction profile, mental disorders

\section{Streszczenie}

Wprowadzenie: Zaburzenia w zakresie neurotransmisji układu nagrody wymieniane są jako jedna z najważniejszych przyczyn uzależnienia. Szczególną rolę przypisuje się tutaj zmienności genetycznej. W literaturze przedmiotu wymienia się przede wszystkim geny neurotransmisji dopaminy: DAT (transportera dopaminy), DRD2 (receptora dopaminy D2), DRD4 (receptora dopaminy D4). Jednak jak dotąd istnieje niewiele doniesień literaturowych na temat tych genów w kontekście innowatorów w terapii uzależnień.

Cel: Analiza związku między zmiennością specyficznych polimorfizmów w genach DRD2 (rs1799732), ANKK1 (rs1800497), DAT (rs28363170), DRD4 (ekson 3 - VNTR) z występowaniem nawrotów u osób uzależnionych od substancji psychoaktywnych.

Materiał i metody: Badania przeprowadzono na grupie 301 osób uzależnionych od środków psychoaktywnych przebywających w ośrodku terapii uzależnień w województwach lubuskim i zachodniopomorskim w Polsce. Grupę kontrolną stanowiło 301 osób, u których nie stwierdzono uzależnienia od substancji psychoaktywnych i zaburzeń psychicznych. Badanie polimorfizmów DRD2 (rs 1799732), ANKK1 (rs1800497) przeprowadzono metodą real-time PCR; natomiast DAT (rs28363170), DRD4 (ekson 3 - VNTR) genotypowano za pomocą PCR i amplifikowane produkty wizualizowano stosując elektroforezę żelową barwioną bromkiem etydyny (3\% agaroza) i fotografię UV. 
Wyniki: Badanie wykazało, że u osób uzależnionych częstości genotypu polimorfizmu VNTR w trzecim eksonie ludzkiego $D R D 4$ były następujące: S/L u 33,55\%, S/S - 63,12\% i L/L - 3,32\%; natomiast w grupie kontrolnej S/L - 32,56\%, S/S - 58,8\% i L/L - 8,6\% $(\chi 2=7,617, p=0,022)$. Zaobserwowano istotne różnice w częstości polimorfizmu rs1799732 genu DRD2 (częstość alleli; $\chi 2=$ $5,48, p=0,0192)$ oraz polimorfizmu VNTR genu DRD4 ( $\chi 2=7,687, p=0,021)$ pomiędzy osobami uzależnionymi od substancji psychoaktywnych, które przebywają na w szpitalnym ośrodku leczniczym i grupie kontrolnej.

Słowa kluczowe: gen, nawroty uzależnienia, profil uzależnienia, zaburzenia psychiczne

\section{Introduction}

Disturbances in the neurotransmission of the reward system are mentioned as one of the most important causes of addiction development [1]. Understanding the causes of neurotransmission dysfunction in addictions is important because it allows for bolder use of various forms of pharmacotherapy, which could significantly affect the effectiveness of treatment of this disorder much higher than the current one. Along with the wider knowledge about the mechanisms of disturbed neurotransmission, the genetic basis of these disorders becomes important. Dysfunctions of this system also occur in other disorders, such as eating disorders, sexual disorders, impulse control disorders or other functional disorders, such as pathological gambling. Correlations with the reward system and disorders in it are also visible, among others in ADHD, mania, obsessive-compulsive disorders. They are also marked in disorders of the motivation of actions occurring in depression, apathy, dementia, and schizophrenia [2].

The causes of neurodevelopmental disorders in the prefrontal cortex are complex and relate to both synaptic formation and neurotransmitter structures. These include various environmental forms of prenatal stress (iron deficiency, exposure to lead, maternal smoking) and perinatal stress. One of the most important causes of neurodevelopmental disorders in the prefrontal cortex that affect impulsivity, best known in the case of ADHD may have genetic factors. Above all, the genes for dopamine neurotransmission are DAT (dopamine transporter), DRD2 (dopamine receptor D2), DRD4 (dopamine receptor D4), $D B H$ (dopamine beta hydroxylase) and other ADRA-2A (alpha - 2A adrenergic receptor), SNAP25 (synaptosome associated protein 25), 5-HTT (serotonin transporter), HTR1B (serotonin 5-HT-1B receptor), FADS2 (fatty acid desaturase 2). Dopaminergic brain systems play important roles since dopamine is the major neurotransmitter of the nigrostriatal system and is involved in the control of motor function, cognition and affect. The human dopamine transporter (DAT1) is a member of the sodium and chloride-dependent neurotransmitter transporter family and contains 12 transmembrane domains. The dopamine transporter (DAT) terminates the synaptic transmission by the rapid and specific reuptake of dopamine into the presynaptic nerve terminals. Psychostimulants, such as cocaine and amphetamine, are known to bind the dopamine transporter and inhibit dopamine reuptake. In $D A T$ knockout mice, dopamine clearance is prolonged and the mice show spontaneous hyperactivity. The reduction in dopamine reuptake results in adaptive changes such as a decreased content of dopamine in presynaptic terminals, significant downregulation of D1 and D2 receptor expression, and a loss of tyrosine hydroxylase. A 40-bp variable number of tandem repeat (VNTR) polymorphism is found in the 3'-untranslated region (3'-UTR) of the DAT gene. Several groups have studied the association between the VNTR polymorphism (rs28363170) DAT and some neuropsychiatric disorders [3].

The D2 dopamine receptor is a G protein-coupled receptor located on postsynaptic dopaminergic neurons that is centrally involved in reward-mediating mesocorticolimbic pathways. Signaling through dopamine D2 receptors governs physiologic functions related to locomotion, hormone production, and drug abuse. D2 receptors are also known as targets of antipsychotic drugs that are used to treat neuropsychiatric disorders.

Another D4 dopamine receptor, that responds to endogenous dopamine is encoded by $D R D 4$ gene located on the short arm of chromosome 11. A variable number of tandem repeats (VNTR) polymorphism in exon 3 DRD4 impacts the length of the protein in the receptor's third cytoplasmic loop, altering receptor sensitivity. This 48 base pair sequence is repeated between 2 and 11 times with the most common versions being 2, 4 and 7 repeats [4].

The connections that are part of the limbic system are especially important in addicts; orbital-cortical cortex with nucleus accumbens. In order to trigger a response in it, the stimulus must have the appropriate motivational force (salience - a stimulus with an increased motivational rank). However, if it occurs immediately, without judgment or reflection, it can trigger a gratifying surge of dopamine in the nucleus accumbens. This way of acting is typical of impulsive people, and this feature, along with the characterological search for novelty and avoidance of punishment, increases the risk of drug addiction [5].

Several studies have assessed the dysfunction of the dopaminergic system in people addicted to alcohol by 
stimulating its activity, looking for a biological marker of susceptibility to relapse [6,7]. Such a marker was considered to be a decreased secretion of growth hormone stimulated by the administration of apomorphine agonistically acting to dopamine receptors stimulating its release in patients with relapse occurring after 3 or 6 months [6,7]. Another would be smaller increases in the level of dopamine-dependent prolactin after administration of haloperidol in the group of patients at risk of relapse, suggesting a weakening of the receptor sensitivity of the dopaminergic system [8].

\section{The aim}

Analysis of the relationship between the variability of specific polymorphisms in the dopamine receptor gene DRD2 (rs1799732), ANKK1 (rs1800497), DAT (rs28363170), DRD4 (exon 3 - VNTR) with the occurrence of relapses in people addicted to psychoactive substances.

\section{Material and methods}

The research was carried out on a group of 301 men addicted to psychoactive substances staying in an addiction therapy center in Lubuskie and Zachodniopomorskie voivodships. The subjects were divided into two groups. The first group consisted of addicts with reported one-time therapy (age 27.4 (SD $=6.22$ )). The second group consisted of addicts who received at least two treatments at an addiction treatment center (28.9 (SD = 6.58)). Both of these groups were compared with the control group of 301 men (22.1 (SD = 4.57)) who had no psychiatric disorders nor addiction to psychoactive substances in the psychiatric examination. To define the subtypes of addiction, the Polish version of the International Classification of Diseases ICD-10 was used. The recruited persons gave their voluntary written consent to participate in the study. Addicts were recruited and in treatment and therapy centers they were in a state of abstinence for not less than three months to minimize the impact of addictive substances on the results of psychometric tests. The approval of the Bioethics Committee of the Pomeranian Medical University in Szczecin was obtained (KB-0012/106/16).

The DNA was isolated from venous blood leukocytes $(10 \mathrm{ml})$ by the salting method according to Miller. To determine the ANKK1 (rs1800497), DRD2 (rs1799732) polymorphisms a real-time PCR method that uses the melting curve analysis method for the alleles tested [LightCycler II apparatus, Roche Diagnostics]. The following melting curves for the ANKK1 polymorphism (rs1800497), 58.95 ${ }^{\circ} \mathrm{C}$ for the $\mathrm{T}$ allele (A1) and 67.17 ${ }^{\circ} \mathrm{C}$ for the $\mathrm{C}$ allele (A2) were used. However, for the polymorphism of the $D R D 2$ gene (rs1799732), $56.64{ }^{\circ} \mathrm{C}$ for the $\mathrm{C}$ allele and $62.85^{\circ} \mathrm{C}$ for the $(-)$ allele.
The DAT genotypes (rs28363170) were grouped according to the presence of nine or ten repeat variants. Genotyping was performed using the PCR-VNTR method, with primers: F: 5'-TGT GGT GTA GGG AAC GGC CTG AG - 3', R: 5'-CTT CCT GGA GGT CAC GGC TCA AGG -3'; in the final volume of $25 \mathrm{uL} P C R$ mix per reaction, with $100 \mathrm{ng}$ genomic DNA, $10 \mathrm{pmol}$ of primers, $50 \mathrm{mM} \mathrm{KCl}, 10 \mathrm{mM}$ TrisHCl, 1.5 mM MgCl2, $200 \mathrm{M} \mathrm{dATP,} \mathrm{dCTP,} \mathrm{dTTP,} \mathrm{dGTP,} \mathrm{and} 0.8 \mathrm{U}$ of the Tag polymerase. The conditions for the reaction were as follows: $5 \mathrm{~min}$ of initial denaturation in $94^{\circ} \mathrm{C}, 55 \mathrm{~s}$ of denaturation in $94^{\circ} \mathrm{C}, 50 \mathrm{~s}$ of primer hybridization in $55^{\circ} \mathrm{C}$, and 1 min of elongation in $72^{\circ} \mathrm{C}$, repeated in 30 cycles, with $10 \mathrm{~min}$ of final elongation in $72^{\circ} \mathrm{C}$. The amplified products were visualized using ethidium bromide stained gel electrophoresis (3\% agarose) and UV photography. The products were $450 \mathrm{bp}$ in length for 10 repeat alleles and $410 \mathrm{bp}$ for nine repeat alleles [9].

The DRD4 genotypes (exon 3 - VNTR) were grouped based on the presence of the short (2-5 repeat) and long (6-11 repeat) variants. Genotyping was performed using the PCR-VNTR method with the following primers: F: 5'- GCG ACT ACG TGG TCT ACT CG -3', R: 5'- AGG ACC CTC ATG GCC TTG - 3'; in the final volume of 25 uL PCR mix per reaction, with $100 \mathrm{ng}$ genomic DNA, 10 pmol of primers, $50 \mathrm{mMKCl}, 10 \mathrm{mM}$ TrisHCl, $1.5 \mathrm{mM} \mathrm{MgCl} 2,200$ _M dATP, dCTP, dTTP, dGTP and $0.8 \mathrm{U}$ of the Tag polymerase. The conditions for the reaction: $3 \mathrm{~min}$ of initial denaturation in $95^{\circ} \mathrm{C}$, cycling $30 \mathrm{~s}$ of denaturation in $95^{\circ} \mathrm{C}, 1 \mathrm{~min}$ of primers hybridization in $63^{\circ} \mathrm{C}$ and $30 \mathrm{~s}$ of elongation in $72^{\circ} \mathrm{C}$, repeated in 35 cycles, $5 \mathrm{~min}$ of final elongation in $72^{\circ} \mathrm{C}$. The amplified products were visualized using ethidium bromide stained gel electrophoresis (3\% agarose) and UV photography. The products ranged from 379 bp (2 repeats) to 811 (11 repeats). The products were divided into two groups: short alleles (S, 2-5 repeats) and long alleles (L, 6-11 repeats) [9].

Statistical analysis was performed using the Chi2 $(\chi 2)$ test in the differences in frequency in individual gene and allele polymorphisms. AFTER comparing the addiction profile, the Chi2 $(\chi 2)$ test and the Spearman's rank correlation were used. In the cases of using the Chi2 test and the Spearman's rank correlation, $\mathrm{p} \leq 0.05$ were assumed as significant statistical differences. All calculations were performed using the STATISTICA 13 package.

\section{Results}

Comparing people addicted to psychoactive substances having a single stay in an inpatient therapy center with people addicted to psychoactive substances having multiple stays in an inpatient therapy center, significant statistical differences in the following phenotypic features were found: mental disorders and 
behavior resulting from alcohol use (F10.2), psychiatric and behavioral disorders due to opiate use (F11.2), mental and behavioral disorders due to sedative and hypnotic drugs (F13.2), mental and behavioral disorders due to stimulant use (F15.2), mental and behavioral disorders from mixed addiction (F19.2) (Table 1).

In people addicted to psychoactive substances with a single stay in an inpatient treatment center, mental disorders and behavior resulting from alcohol use (F10.2) were noted in $40.52 \%$ and in $59.48 \%$ no alcohol addiction was found. On the other hand, in people addicted to psychoactive substances who had multiple visits in an inpatient treatment center, mental disorders and behaviors resulting from alcohol use were $70.27 \%$, and $29.73 \%$ were not addicted to alcohol $(\chi 2=26.914, p$ $=0.000$ ). There was a positive correlation of Spearman's rank associated with an increase in the frequency of mental and behavioral disorders caused by alcohol consumption associated with a greater number of visits to the treatment center in an inpatient facility $(R=0.299, \mathrm{p}=$ 0.000) (Table 1).

In people addicted to psychoactive substances with a one-time stay in an inpatient treatment center, mental disorders and behavior resulting from opiate use (F11.2) were noted in $15.03 \%$ and $84.97 \%$ were not addicted to opiates. On the other hand, in people addicted to psychoactive substances with multiple stays in inpatient treatment centers, mental and behavioral disorders

Table 1. Comparison of the addiction profile in a group of people participating in single therapy and with relapses in treatment in an inpatient facility.

\begin{tabular}{|c|c|c|c|c|c|}
\hline & & \multirow{2}{*}{$\begin{array}{l}\text { People } \\
\text { participating in } \\
\text { the therapy once } \\
(\mathrm{N}=153)\end{array}$} & \multirow{2}{*}{$\begin{array}{l}\text { People with } \\
\text { relapses in } \\
\text { therapy } \\
(\mathrm{N}=148)\end{array}$} & $\begin{array}{l}\text { The rank of } \\
\text { Spearman }\end{array}$ & Test $\chi 2$ \\
\hline & & & & $\begin{array}{c}\mathrm{R} \\
(\mathrm{p})\end{array}$ & $\begin{array}{l}\chi 2 \\
(p)\end{array}$ \\
\hline \multirow{2}{*}{$\begin{array}{l}\text { Behavioral } \\
\text { addictions }\end{array}$} & not & $87(56.9 \%)$ & $86(58.1 \%)$ & \multirow{2}{*}{$\begin{array}{l}-0.013 \\
(0.828)\end{array}$} & \multirow{2}{*}{$\begin{array}{c}0.048 \\
(0.827)\end{array}$} \\
\hline & yes & $66(43.1 \%)$ & $62(41.9 \%)$ & & \\
\hline \multirow{2}{*}{ Addiction boosters } & not & $117(76.5 \%)$ & $111(75 \%)$ & \multirow{2}{*}{$\begin{array}{c}0.017 \\
(0.767)\end{array}$} & \multirow{2}{*}{$\begin{array}{c}0.089 \\
(0.766)\end{array}$} \\
\hline & yes & $36(23,53 \%)$ & $37(25,00 \%)$ & & \\
\hline \multirow{2}{*}{ F10.2-alcohol } & not & $91(59.5 \%)$ & $44(29.7 \%)$ & \multirow{2}{*}{$\begin{array}{c}0.299 \\
(0.000)\end{array}$} & \multirow{2}{*}{$\begin{array}{l}26.914^{*} \\
(0.000)\end{array}$} \\
\hline & yes & $62(40.5 \%)$ & $104(70.3 \%)$ & & \\
\hline \multirow{2}{*}{ F11.2-opiates } & not & $130(85 \%)$ & $110(74.3 \%)$ & \multirow{2}{*}{$\begin{array}{c}0.132 \\
(0.022)\end{array}$} & \multirow{2}{*}{$\begin{array}{c}5.274^{*} \\
(0.022)\end{array}$} \\
\hline & yes & $23(15 \%)$ & $38(25.7 \%)$ & & \\
\hline \multirow{2}{*}{ F12.2-cannabis } & not & $46(30 \%)$ & $41(27.7 \%)$ & \multirow{2}{*}{$\begin{array}{c}0.026 \\
(0.653)\end{array}$} & \multirow{2}{*}{$\begin{array}{c}0.204 \\
(0.651)\end{array}$} \\
\hline & yes & $107(69.9 \%)$ & $107(72.3 \%)$ & & \\
\hline \multirow{2}{*}{$\begin{array}{l}\text { F13.2- sedatives } \\
\text { and sleeping pills }\end{array}$} & not & $143(93.46 \%)$ & $120(81.1 \%)$ & \multirow{2}{*}{$\begin{array}{c}0.186 \\
(0.001)\end{array}$} & \multirow{2}{*}{$\begin{array}{l}10.458^{*} \\
(0.001)\end{array}$} \\
\hline & yes & $10(6.54 \%)$ & $28(18.9 \%)$ & & \\
\hline \multirow{2}{*}{ F14.2-cocaine } & not & $139(90.8 \%)$ & $131(88.5 \%)$ & \multirow{2}{*}{$\begin{array}{c}0.038 \\
(0.507)\end{array}$} & \multirow{2}{*}{$\begin{array}{c}0.444 \\
(0.505)\end{array}$} \\
\hline & yes & $14(9.1 \%)$ & $17(11.5 \%)$ & & \\
\hline \multirow{2}{*}{$\begin{array}{l}\text { F15.2-stimulating } \\
\text { substances }\end{array}$} & not & $20(13.1 \%)$ & $34(23 \%)$ & \multirow{2}{*}{$\begin{array}{l}-0.129 \\
(0.025)\end{array}$} & \multirow{2}{*}{$\begin{array}{c}5.009 * \\
(0.025)\end{array}$} \\
\hline & yes & $133(86.9 \%)$ & $114(77 \%)$ & & \\
\hline \multirow{2}{*}{$\begin{array}{c}\text { F16.2- } \\
\text { hallucinogenic }\end{array}$} & not & $142(92.8 \%)$ & $128(86.5 \%)$ & \multirow{2}{*}{$\begin{array}{c}0.104 \\
(0.072)\end{array}$} & \multirow{2}{*}{$\begin{array}{c}3.257 \\
(0.071)\end{array}$} \\
\hline & yes & $11(7.2 \%)$ & $20(13.5 \%)$ & & \\
\hline \multirow{2}{*}{ F17.2-tobacco } & not & $151(98.69 \%)$ & $147(99.3)$ & \multirow{2}{*}{$\begin{array}{l}-0.032 \\
(0.583)\end{array}$} & \multirow{2}{*}{$\begin{array}{c}0.304 \\
(0.581) \\
\end{array}$} \\
\hline & yes & $2(1.31 \%)$ & $1(0,7 \%)$ & & \\
\hline \multirow{2}{*}{$\begin{array}{l}\text { F18.2-volatile } \\
\text { solvents }\end{array}$} & not & $151(98.7 \%)$ & $148(100 \%)$ & -0.080 & 1.948 \\
\hline & yes & $2(1.3 \%)$ & $0(0.0 \%)$ & $(0.164)$ & $(0.163)$ \\
\hline F19.2-mixed & not & $82(53.6 \%)$ & 47 (31.8) & 0.221 & $14.650^{*}$ \\
\hline addiction & yes & $71(46.4 \%)$ & $101(68.2 \%)$ & $(0.000)$ & $(0.000)$ \\
\hline
\end{tabular}

*Siginificant statistical differences 
caused by opiate use were $25.68 \%$, and $74.32 \%$ were not addicted to opiates $(\chi 2=5.274, \mathrm{p}=0.022)$. There was a positive correlation of Spearman's rank associated with an increase in the incidence of mental and behavioral disorders caused by opiate use associated with a greater number of inpatient treatment centers $(\mathrm{R}=0.132, \mathrm{p}=$ 0.022) (Table 1).

In people addicted to psychoactive substances with a one-time stay in an inpatient treatment center, mental disorders and behavior resulting from the use of sedatives and hypnotics (F13.2) were noted in $6.54 \%$ and in $93.46 \%$ no addiction to sedatives and hypnotics. On the other hand, in people addicted to psychoactive substances with multiple visits to an inpatient treatment center, mental and behavioral disorders resulting from the use of sedatives and hypnotics were found to be $18.92 \%$, and $81.08 \%$ were not addicted to sedatives and hypnotics $(\chi 2=10.458, \mathrm{p}$ $=0.001)$. There was a positive correlation of Spearman's rank associated with an increase in the frequency of mental and behavioral disorders resulting from the use of sedatives and hypnotics associated with a greater number of stay in the treatment center in an inpatient center $(\mathrm{R}=$ $0.186, \mathrm{p}=0.001$ ) (Table 1 ).

In people addicted to psychoactive substances with a one-time stay in an inpatient treatment center, mental disorders and behavior caused by the use of stimulants (F15.2) were noted in $86.93 \%$ and in $13.07 \%$ no addiction to stimulants was found. On the other hand, in people

Table. 2. Comparison of Genotypic traits and alleles of the group of people addicted to psychoactive substances and the control group.

\begin{tabular}{|c|c|c|c|c|}
\hline \multicolumn{2}{|c|}{ genotype * / alleles ** } & \multirow{2}{*}{$\begin{array}{c}\begin{array}{c}\text { People addicted } \\
\text { to psychoactive } \\
\text { substances }(\mathrm{N}=301)\end{array} \\
9(2.9 \%)\end{array}$} & \multirow{2}{*}{$\begin{array}{c}\begin{array}{c}\text { Control group } \\
(\mathrm{N}=301)\end{array} \\
4(1.3 \%)\end{array}$} & $\chi^{2}$ \\
\hline \multirow{5}{*}{$\begin{array}{c}D R D 2 \\
\text { (rs 1799732) }\end{array}$} & del/del* & & & \multirow{3}{*}{$\begin{array}{c}3.706 \\
(0.157)\end{array}$} \\
\hline & ins/ins* & $224(74.4 \%)$ & $241(80.1 \%)$ & \\
\hline & ins/del* & $68(22.6 \%)$ & $56(18.6 \%)$ & \\
\hline & del $^{* *}$ & $86(14.3 \%)$ & $64(10.6 \%)$ & \multirow{2}{*}{$\begin{array}{c}3.69 \\
(0.055)\end{array}$} \\
\hline & ins $* *$ & $516(85.7 \%)$ & $538(89.4 \%)$ & \\
\hline \multirow{5}{*}{$\begin{array}{c}A N K K 1 \\
\text { (rs 1800497) }\end{array}$} & $\mathrm{C} / \mathrm{C}^{*}$ & $189(62.8 \%)$ & $199(66.3 \%)$ & \multirow{3}{*}{$\begin{array}{c}2.186 \\
(0.335)\end{array}$} \\
\hline & $\mathrm{C} / \mathrm{T}^{*}$ & $99(32.9 \%)$ & $94(31.3 \%)$ & \\
\hline & $\mathrm{T} / \mathrm{T}^{*}$ & $13(4.3 \%)$ & $7(2.3 \%)$ & \\
\hline & $\mathrm{C}^{* *}$ & $477(79.2 \%)$ & $492(82 \%)$ & \multirow{2}{*}{$\begin{array}{c}1.47 \\
(0.226)\end{array}$} \\
\hline & $\mathrm{T}^{* *}$ & $125(20.8 \%)$ & $108(18 \%)$ & \\
\hline \multirow{5}{*}{$\begin{array}{c}D A T \\
(\mathrm{rs} 28363170)\end{array}$} & $9 / 10^{*}$ & $123(40.9 \%)$ & $114(37.9 \%)$ & \multirow{3}{*}{$\begin{array}{c}3.916 \\
(0.141)\end{array}$} \\
\hline & 9/9* & $9(2.9 \%)$ & $19(6.3 \%)$ & \\
\hline & $10 / 10 *$ & $169(56.1 \%)$ & $168(55.8 \%)$ & \\
\hline & $9 * *$ & $141(23.4 \%)$ & $152(25.2 \%)$ & 0.55 \\
\hline & $10^{* *}$ & $461(76.6 \%)$ & $450(74.7 \%)$ & $(0.460)$ \\
\hline \multirow{5}{*}{$\begin{array}{c}D R D 4 \\
\text { (exon } 3-\text { VNTR) }\end{array}$} & $\mathbf{S} / \mathbf{L}^{*}$ & $101(33.5 \%)$ & $98(32.6 \%)$ & \multirow{3}{*}{$\begin{array}{c}7.617 \\
(0.022) \#\end{array}$} \\
\hline & $\mathbf{S} / \mathbf{S}^{*}$ & $190(63.1 \%)$ & $177(58.8 \%)$ & \\
\hline & $\mathbf{L} / \mathbf{L}^{*}$ & $10(3.3 \%)$ & $26(8.6 \%)$ & \\
\hline & $\mathbf{S}^{* *}$ & $481(79.9 \%)$ & $452(75.1 \%)$ & \multirow{2}{*}{$\begin{array}{c}4.00 \\
(0.045) \#\end{array}$} \\
\hline & $\mathbf{L}^{* *}$ & $121(20.1 \%)$ & $150(24.9 \%)$ & \\
\hline
\end{tabular}

${ }^{*}$-genotype, ${ }^{* *}$ - alleles, \#-statistically significant differences 
addicted to psychoactive substances with multiple stays in inpatient treatment centers, mental disorders and behavior resulting from the use of stimulants were found to be $77.03 \%$, and $22.97 \%$ were not addicted to stimulants $(\chi 2=5.009, p=0.025)$. There was a negative correlation of Spearman's rank associated with an increase in the frequency of mental and behavioral disorders caused by the use of stimulants associated with a greater number of in-patient treatment centers $(\mathrm{R}=-0.129, \mathrm{p}=0.025$ ) (Table 1).

In people addicted to psychoactive substances with a single stay in an inpatient treatment center, mental and behavioral disorders caused by mixed addiction (F19.2) were noted in $46.41 \%$ and in $53.59 \%$ no mixed addiction was found. On the other hand, in people addicted to psychoactive substances with multiple stays in inpatient treatment centers, mental and behavioral disorders caused by mixed addiction were $68.24 \%$, and $31.76 \%$ lacked mixed addiction $(\chi 2=14.650, p=0.000)$. There was a positive correlation of Spearman's rank associated with an increase in the frequency of mental and behavioral disorders caused by mixed addiction connected with a greater number of in-patient treatment centers $(R=0.221$, $\mathrm{p}=0.000)($ Table 1$)$.

\section{Polymorphism of genotypic traits and alleles}

Significant differences were observed in the frequency of DRD4 polymorphism (exon 3 - VNTR)

Table. 3. Comparison of genotypic traits and alleles of relapsers in therapy and the control group.

\begin{tabular}{|c|c|c|c|c|}
\hline \multicolumn{2}{|c|}{ genotype $* /$ alleles $* *$} & \multirow{2}{*}{$\begin{array}{l}\text { People with } \\
\text { relapses in therapy } \\
(\mathrm{N}=148) \\
5(3.4 \%)\end{array}$} & \multirow{2}{*}{$\begin{array}{c}\begin{array}{c}\text { Control group } \\
(\mathrm{N}=301)\end{array} \\
4(1.3 \%)\end{array}$} & \multirow{4}{*}{$\begin{array}{c}\chi^{2} \\
(\mathrm{p}) \\
\\
\\
2.122 \\
0.346\end{array}$} \\
\hline \multirow{5}{*}{$\begin{array}{c}\text { DRD2 } \\
\text { (rs 1799732) }\end{array}$} & del/del* & & & \\
\hline & ins/ins* & $116(78.4 \%)$ & $241(80.1 \%)$ & \\
\hline & ins/del* & $27(18.2 \%)$ & $56(18.6 \%)$ & \\
\hline & $\mathrm{del}^{* *}$ & $37(12.5 \%)$ & $64(10.6 \%)$ & \multirow{2}{*}{$\begin{array}{c}0.69 \\
(0.405)\end{array}$} \\
\hline & ins $* *$ & $259(87.5 \%)$ & $538(89.4 \%)$ & \\
\hline \multirow{5}{*}{$\begin{array}{c}A N K K 1 \\
\text { (rs 1800497) }\end{array}$} & $\mathrm{C} / \mathrm{C}^{*}$ & $95(64.2 \%)$ & $199(66.3 \%)$ & \multirow{3}{*}{$\begin{array}{c}4.050 \\
(0.132)\end{array}$} \\
\hline & $\mathrm{C} / \mathrm{T}^{*}$ & $44(29.7 \%)$ & $94(31.3 \%)$ & \\
\hline & $\mathrm{T} / \mathrm{T}^{*}$ & $9(6.1 \%)$ & $7(2.3 \%)$ & \\
\hline & $\mathrm{C}^{* *}$ & $234(79.1 \%)$ & $492(82 \%)$ & \multirow{2}{*}{$\begin{array}{c}1.12 \\
(0.290)\end{array}$} \\
\hline & $\mathrm{T}^{* *}$ & $62(20.9 \%)$ & $108(18 \%)$ & \\
\hline \multirow{5}{*}{$\begin{array}{c}D A T \\
(\mathrm{rs} 28363170)\end{array}$} & $9 / 10^{*}$ & $63(42.6 \%)$ & $114(37.9 \%)$ & \multirow{3}{*}{$\begin{array}{c}2.208 \\
(0.332)\end{array}$} \\
\hline & 9/9* & $5(3.4 \%)$ & $19(6.3 \%)$ & \\
\hline & $10 / 10 *$ & $80(54.1 \%)$ & $168(55.8 \%)$ & \\
\hline & $9 * *$ & $73(24,7 \%)$ & $152(25.2 \%)$ & 0.04 \\
\hline & $10^{* *}$ & $223(75.3 \%)$ & $450(74.7 \%)$ & $(0.849)$ \\
\hline \multirow{5}{*}{$\begin{array}{c}D R D 4 \\
\text { (exon } 3-\text { VNTR) }\end{array}$} & $\mathbf{S} / \mathbf{L}^{*}$ & $45(30.1 \%)$ & $98(32.6 \%)$ & \multirow{3}{*}{$\begin{array}{c}2.806 \\
(0.246)\end{array}$} \\
\hline & $\mathbf{S} / \mathbf{S}^{*}$ & $96(64.9 \%)$ & $177(58.8 \%)$ & \\
\hline & $\mathbf{L} / \mathbf{L}^{*}$ & $7(4.7 \%)$ & $26(8.6 \%)$ & \\
\hline & $\mathbf{S}^{* *}$ & $237(80.1 \%)$ & $452(75.1 \%)$ & \multirow{2}{*}{$\begin{array}{c}2.76 \\
(0.097)\end{array}$} \\
\hline & $\mathbf{L}^{* *}$ & $59(19.9 \%)$ & $150(24.9 \%)$ & \\
\hline
\end{tabular}

*-genotype, ${ }^{* *}$ - alleles, \#-statistically significant differences 
between the addicted to psychoactive substances and the control group. This study showed that in addicts genotype frequencies of the VNTR polymorphism in the third exon of human DRD4 were as follow: S/L in 33.55\%, S/S - $63.12 \%$ and L/L - 3.32\%; while in the control group S/L $32.56 \%, \mathrm{~S} / \mathrm{S}-58.8 \%$ and $\mathrm{L} / \mathrm{L}-8.6 \%(\chi 2=7.617, \mathrm{p}=0.022)$.

For the DRD4 VNTR polymor phism addicts had $79.9 \%$ $\mathrm{S}$ alleles and $20.10 \% \mathrm{~L}$ alleles while the control group had S alleles $-75.08 \%$, L alleles $-24.92 \%(\chi 2=4.00, p=0.045)$ (Table 2).

Differences on the border of statistical significance were shown between the addicts with multiple visits to an inpatient treatment center and the control group in the frequency of the following gene polymorphisms: ANKK1 (rs1800497) $(\chi 2=4.050, \mathrm{p}=0.132)$ and $D R D 4$ (exon $3-$ VNTR) "short" and "long" variants $(\chi 2=2.76, \mathrm{p}=0.097)$ (Table 3).

Significant differences in the frequency of $D R D 2$ gene polymorphism (rs1799732) and DRD4 (exon 3 -VNTR) were observed between the addicted to psychoactive substances with a single stay in an inpatient treatment center and the control group. The DRD2 gene (rs1799732) allele polymorphism occurs in addicts who have a single stay in an inpatient treatment center: del in $16.07 \%$, ins $-83.93 \%$, while in people from the control group del in $10.63 \%$, ins $-89.37 \%(\chi 2=5.48, p=0.0192)$. For the DRD4 (exon 3 -VNTR) in people addicted to psychoactive substances with a one-time stay in an inpatient treatment

Table. 4. Comparison of genotypic features and alleles of people with one-time therapy and the control group.

\begin{tabular}{|c|c|c|c|c|}
\hline \multicolumn{2}{|c|}{ genotype $*$ / alleles $* *$} & \multirow{2}{*}{$\begin{array}{c}\text { People with one- } \\
\text { time therapy } \\
(\mathrm{N}=153))\end{array}$} & \multirow{2}{*}{$\begin{array}{l}\text { Control group } \\
(\mathrm{N}=301)\end{array}$} & $\begin{array}{l}\chi^{2} \\
(p)\end{array}$ \\
\hline \multirow{5}{*}{$\begin{array}{c}D R D 2 \\
\text { (rs 1799732) }\end{array}$} & del/del* & & & \multirow{3}{*}{$\begin{array}{c}5.323 \\
(0.070)\end{array}$} \\
\hline & ins/ins* & $108(70.6 \%)$ & $241(80.1 \%)$ & \\
\hline & ins/del* & $41(26.8 \%)$ & $56(18.6 \%)$ & \\
\hline & $\mathrm{del}^{* *}$ & $49(16.1 \%)$ & $64(10.6 \%)$ & \multirow{2}{*}{$\begin{array}{c}5.48 \\
(0.0192) \#\end{array}$} \\
\hline & ins $* *$ & $256(83.9 \%)$ & 538 (89.4\%) & \\
\hline \multirow{5}{*}{$\begin{array}{c}A N K K 1 \\
\text { (rs 1800497) }\end{array}$} & $\mathrm{C} / \mathrm{C}^{*}$ & $94(61.4 \%)$ & $199(66.3 \%)$ & \multirow{3}{*}{$\begin{array}{c}1.064 \\
(0.587)\end{array}$} \\
\hline & $\mathrm{C} / \mathrm{T}^{*}$ & $55(35.9 \%)$ & $94(31.3 \%)$ & \\
\hline & $\mathbf{T} / \mathbf{T}^{*}$ & $4(2.61 \%)$ & $7(2.3 \%)$ & \\
\hline & $\mathrm{C}^{* *}$ & $243(79.4 \%)$ & $492(82 \%)$ & \multirow{2}{*}{$\begin{array}{c}0.89 \\
(0.346)\end{array}$} \\
\hline & $\mathrm{T}^{* *}$ & $63(20.6 \%)$ & $108(18 \%)$ & \\
\hline \multirow{5}{*}{$\begin{array}{c}D A T \\
(\mathrm{rs} 28363170)\end{array}$} & $9 / 10 *$ & $60(39.2 \%)$ & $114(37.9 \%)$ & \multirow{3}{*}{$\begin{array}{c}2.885 \\
(0.236)\end{array}$} \\
\hline & 9/9* & $4(2.6 \%)$ & $19(6.3 \%)$ & \\
\hline & $10 / 10 *$ & $89(58.2 \%)$ & $168(55.8 \%)$ & \\
\hline & $9 * *$ & $68(22.2 \%)$ & $152(25.2 \%)$ & 1.01 \\
\hline & $10^{* *}$ & $238(77.8 \%)$ & $450(74.7 \%)$ & $(0.314)$ \\
\hline \multirow{5}{*}{$\begin{array}{c}D R D 4 \\
\text { (exon } 3-\text { VNTR) }\end{array}$} & $\mathbf{S} / \mathbf{L}^{*}$ & $56(36.6 \%)$ & $98(32.6 \%)$ & \multirow{3}{*}{$\begin{array}{c}7.687 \\
(0.021) \#\end{array}$} \\
\hline & $\mathbf{S} / \mathbf{S}^{*}$ & $94(61.4 \%)$ & $177(58.8 \%)$ & \\
\hline & $\mathbf{L} / \mathbf{L}^{*}$ & $3(1.9 \%)$ & $26(8.6 \%)$ & \\
\hline & $\mathbf{S}^{* *}$ & $244(79.7 \%)$ & $452(75.1 \%)$ & \multirow{2}{*}{$\begin{array}{c}2.46 \\
(0.117)\end{array}$} \\
\hline & $\mathbf{L}^{* *}$ & $62(20.3 \%)$ & $150(24.9 \%)$ & \\
\hline
\end{tabular}

${ }^{*}$-genotype, ${ }^{* *}$ - alleles, \#-statistically significant differences 
center, genotype frequencies polymorphism were as follow: S/L - 36.60\%, S/S - 61.44\% and L/L - 1.96\%, while in the control group there was S/L - 32.56\%, S/S - 58.80\% and $\mathrm{L} / \mathrm{L}-8.64 \%(\chi 2=7.687, \mathrm{p}=0.021)$ (Table 4$)$.

\section{Discussion}

The genetic aspects of addiction have plagued scientists for many years. Research on genetic markers of addiction to alcohol or other psychoactive substances made it possible to determine many genes, which, in connection with environmental factors, may determine the predisposition to develop addiction. At the moment, we do not know about one, typical and very characteristic biological marker, which would show high sensitivity and specificity and would be responsible for the occurrence or beginning of the addiction process itself [10].

Based on neurobiological premises and the knowledge of the brain's reward system, it is the dopaminergic system that we put at the forefront in considering the factors that predispose to addiction. It is not only the cascade of diabolic learning, but also the translation into genes encoding dopamine receptors and transporter that lead the way in the literature on the subject. A number of other associations related to polymorphic variants of serotonin receptor genes or the opioid and gabaergic systems have also been demonstrated.

Some of the polymorphic variants of the genes encoding dopamine receptor DRD2 [11, 12], DRD3 [13], serotonin 5-HT1B receptor [14], dopamine transporter DAT $[15,16]$, serotonin transporter 5-HTT (SLC6A4) [11, 15] as well as the CB1 cannabinoidergic receptor (CNR1) gene [16] determine the susceptibility to an early onset and significantly worse course of addiction to alcohol and other psychoactive substances.

In the own study, these relationships were taken into account and polymorphisms related to the dopaminergic system were analyzed in the context of relapse. Significant differences in the frequency of DRD2 gene polymorphism (rs1799732) and DRD4 (exon 3 - VNTR) polymorphism were observed between the addicted to psychoactive substances with a single stay in an inpatient treatment center compared to the control group. The DRD2 (rs1799732) gene allele polymorphism occurs in addicts who have a single stay in an inpatient treatment center: allel del in $16.07 \%$, allel ins - $83.93 \%$, while in persons from the control group allel del in $10.63 \%$, allel ins $-89.37 \%(\chi 2=5.48, \mathrm{p}=0.0192)$. For the DRD4 (exon 3 - VNTR) in people addicted to psychoactive substances with a one-time stay in an in-patient treatment center, genotypes were observed: S/L - 36.60\%, S/S - 61.44\% and $\mathrm{L} / \mathrm{L}-1.96 \%$, while in the control group there was S/L - $32.56 \%, \mathrm{~S} / \mathrm{S}-58.80 \%$ and $\mathrm{L} / \mathrm{L}-8.64 \%(\chi 2=7.687, \mathrm{p}=$ $0.021)$.
The relationship between the polymorphism in exon 3 of the DRD4 gene and the occurrence of alcohol dependence and early loss of control over drinking $[17,18]$ as well as between the variant of TPH tryptophan hydroxylase gene in intron 7 and increased susceptibility to addiction has been repeatedly proven [19].

However, in our own research, significant differences were observed in the frequency of polymorphism of the DRD4 (exon 3 - VNTR) between the addicted to psychoactive substances and the control group. This study showed that in addicts genotype frequencies of the VNTR polymorphism in the third exon of human DRD4 were as follow: S/L in 33.55\%, S/S - 63.12\% and L/L - 3.32\%; while in the control group S/L - 32.56\%, S/S - $58.8 \%$ and L/L $8.6 \%(\chi 2=7.617, \mathrm{p}=0.022)$.

For the DRD4 VNTR polymorphism, addicts had $79.9 \% \mathrm{~S}$ alleles, $20.10 \% \mathrm{~L}$ alleles while those from the control group had $75.08 \% \mathrm{~S}$ alleles and $24.92 \%$ L alleles $(\chi 2=4.00, p=0.045)$. There were differences at the border of statistical significance between addicts and the control group in the frequency of the following gene polymorphisms: DRD2 rs1799732 $(\chi 2=3.706, \mathrm{p}=$ 0.157), $D A T$ rs28363170 ( $\chi 2=3.916, \mathrm{p}=0.141)$ and $D R D 2$ rs1799732 allele variants ins and del $(\chi 2=3.69, p=0.055)$.

Reference should also be made to the research under the American COGA project, where researchers describe a high statistically significant correlation of intron 3 of the GABRA2 alpha-2 subunit gene as well as 43 haplotypes composed of single nucleotide polymorphisms (SNPs) of the same region with alcohol dependence [20].

At present, there are few studies dealing with the issue of genetic determinants of addiction relapses. The researchers focus on the analysis of the polymorphism $(\mathrm{A} / \mathrm{G})$ in exon 8 of the $D R D 2$ gene and the relationship between homozygous A/A and early relapses [21,22]. The indicated genotype is also associated with much more intense symptoms of anxiety and depression after the detoxification period, more frequent occurrence of suicide attempts, as well as severe withdrawal syndrome. This study confirms not only the functional importance of polymorphism, but also the decreased activity of the central dopaminergic system in the considered pathogenesis of relapse in addicts. An additional interesting fact is the higher prevalence of the A/A genotype in patients who had a reaction to apomorphine associated with a smaller increase in growth hormone levels [21, 22].

On the other hand, Wiesbeck et al. [23] and his team did not confirm the relationship between the polymorphic variants: -141C ins/del (rs1799732) of DRD2 and DRD3 (Bal I) genes and the occurrence of relapses in addiction during the one-year observation period. In their studies, Heinz et al. [24] strongly questioned the genetic determinants of 
dopamine system insufficiency in addicted patients with unfavorable prognosis and the risk of relapse.

When it comes to the genetic predisposition of addiction, the inference of the risk of recurrence should be very careful. As shown, the results of the studies are contradictory, the analyzes concern different genes and do not conclude by finding a characteristic marker. The creation of haplotypes or GWAS research should be taken into account, as they may shed new light on the subject matter in the future. Additionally, one should remember about the complexity of addiction, many predisposing factors and the environmental component, which is difficult to define unequivocally. Therefore, the next analysis, key in this study, was the analysis of psychological factors in patients with relapses of addiction.

\section{Conclusions}

The analysis of particular genetic predispositions of addiction showed contradictory results. The conducted analysis concerns the polymorphisms of the dopamine receptor genes DRD2 (rs1799732), ANKK1 (rs1800497), DAT (rs28363170), DRD4 (exon 3 - VNTR) and are not concluded by finding a characteristic marker.

\section{Conflict of interest}

The authors have declared no conflict of interest.

\section{References:}

1. Kostkowski W. Dopamina a mechanizm nagrody i rozwój uzależnień; fakty i hipotezy, Alkoholizm i Narkomania 2000: 2, (55), 189-212.

2. Stahl S.M. Podstawy psychofarmakologii: teoria i praktyk. Gdańsk: Via Medica,2010: 181-192.

3. Fuke S, Suo S, Takahashi N, Koike H, Sasagawa N, Ishiura S. The VNTR polymorphism of the human dopamine transporter (DAT1) gene affects gene expression. Pharmacogenomics J. 2001;1(2):152-6.

4. McGeary J. The DRD4 exon 3 VNTR polymorphism and addiction-related phenotypes: a review. Pharmacol Biochem Behav. 2009 Sep;93(3):222-9

5. Sznabowicz M. Analiza polimorfizmów genu receptora dopaminowego DRD2 w kontekście poszukiwania cech zespołu deficytu uwagi w układzie nagrody, w grupie pacjentów uzależnionych od środków psychostymulujących. Rozprawa doktorska. Klinika i Katedra Psychiatrii PUM, Szczecin 2014.

6. Dettling M., Heinz A., Dufeu P., Rommelspacher H., Graf K.J., Schmidt L.G. Dopaminergicresponsivity in alcoholism: trait, state, orresidual marker? American Journal of Psychiatry,1995: 152, 1317-1321.

7. Schmidt L.G., Dettling M., Graef K.J., Heinz A,. Kuhn S., Podschus s, Rommelspachel H. reduced dopaminergic function in alkoholcs is related to severe dependence, Biological Psychiatry,1996: 39, 193-198.

8. Shiffman S. Maintenance and relapse: coping with temptation. W: NirembergTD, Maisto SA, (red.) Developments in the Assessment and Treatment of Addictive Behaviors. Norwood, NJ: Ablex,1987: 353-385.

9. Masiak J, Chmielowiec J, Chmielowiec K, Grzywacz A. DRD4,
DRD2, DAT1, and ANKK1 Genes Polymorphisms in Patients with Dual Diagnosis of Polysubstance Addictions. J Clin Med. 2020 Nov 8;9(11):3593.

10. Samochowiec J. Genetyka molekularna uzależnienia alkoholowego. W: Rybakowski J, Hauser J (red.) Genetyka molekularna zaburzeń psychicznych. Kraków: Komitet Red.Wyd. PTP, 2002: 49-69.

11. Sander T., Harms H., Lesch K.P., Dufeu P., Kuhn S., Hoehe M., Rommelspacher H., Schmidt L.G. Association analysis of a regulatory variation of the serotonin transporter gene with severe alcohol dependence. Alcoholism: Clinical and Experimental Research,1997: 21, 1356-1359.

12. Noble E.P. The D2 dopamine receptor gene: a review of association studies in alcoholism and phenotypes. Alcohol, 1998: 16, 33-45.

13. Sander T., Harms H., Podschus J., Finckh U., Nickel B., Rolfs A., Rommelspacher H., Schmidt L.G. Dopamine D1, D2 and D3 receptor genes in alcohol dependence. Psychiatric Genetics,1995: 5, 171-176.

14. Soyka M., Preuss U.W., Koller G., Zill P., Bondy B. Association of 5-HT1B receptor gene and antisocial behavior in alcoholism. Journal of Neural Transmission, 2004: 111, 101-109.

15. Sander T., Harms H., Dufeu P., Kuhn S., Hoehe M., Lesch K.P., Rommelspacher H., Schmidt L.G. Serotonin transporter gene variants in alcohol-dependent subjects with dissocial personality disorder. Biological Psychiatry,1998: 43, 908-912.

16. Schmidt L.G, Samochowiec J., Finckh U., Fiszer-Piosik E., Horodnicki J., Wendel B., Rommelspacher H., Hoehe M.R. (2002). Association of a CB1 cannabinoid receptor gene (CNR1) polymorphism with severe alcohol dependence. Drug and Alcohol Dependence, 2002: 65, 221-224.

17. Muramatsu T., Higuchi S., Murayama M., Matsushita S., Hayashida M. Association between alcoholism and the dopamine D4 receptor gene. Journal of Medical Genetics,1996: 33, 113-115.

18. Hutchison K.E., McGeary J., Smolen A., Bryan A., Swift R.M. The DRD4 VNTR polymorphism moderates craving after alcohol consumption. Health Psychology, 2002: 21, 139-146.

19. Nielsen D.A., Virkkunen M., Lappalainen J., Eggert M., Brown G.L., Long J.C., Goldman D., Linnoila M. A tryptophan hydroxylase gene marker for suicidality and alcoholism. Archives of General Psychiatry, 1998: 55, 593-602.

20. Covault J., Gelernter J., Hesselbrock V., Nellissery M., Kranzler H.R. Allelic and haplotypic association of GABRA2 with alcohol dependence. American Journal of Medical Genetics, 2004: 129B, 104.109.

21. Finckh U., Rommelspacher H., Kuhn S., Dufeu P., Otto G., Heinz A., Dettling M., Giraldo-Velasquez M, Pelz J., Graf K.J., Harms H., Sander T., Schmidt L.G., Rolfs A. Influence of the dopaminę D2 receptor (DRD2) genotype on neuroadaptive effects of alcohol and the clinical outcome of alcoholism. Pharmacogenetics,1997: 7, 271-281.

22. Samochowiec J., Ladehoff M., Pelz J., Smolka M., Schmidt L.G., Rommelspacher H., Finckh U. Predominant influence of the 3 '-region of dopamine D2 receptor gene (DRD2) on the clinical phenotype in German alcoholics. Pharmacogenetics, 2000: 10, 471-475.

23. Wiesbeck G.A., Weijers H.G., Wodarz N., Herrmann M.J., Johann M., Keller H.K., Michel T.M., Boning J. Dopamine D2 (DAD2) and dopamine D3 (DAD3) receptor gene polymorphisms and treatment outcome in alcohol dependence. Journal of Neural Transmission, 2003: 110, 813-820.

24. Heinz A., Sander T., Harms H., Finckh U., Kuhn S., Dufeu P., Dettling M., Graf K., Rolfs A., Rommelspacher H., Schmidt L.G. 
Lack of allelic association of dopamine D1 and D2 (TaqIA) receptor gene polymorphisms with reduced dopaminergic sensitivity to alcoholism. Alcoholism: Clinical and Experimental Research, 1996: 20, 1109-1113.

\section{Corresponding author}

Dr Jolanta Chmielowiec

Department of Hygiene and Epidemiology, Collegium

Medicum, University of Zielona Góra,

Zyty 28 St., 65-046 Zielona Góra, Poland

e-mail: j.chmielowiec@wlnz.uz.zgora.pl

Otrzymano: 08.01.2021

Zrecenzowano:19.01.2021

Przyjęto do druku: 18.02.2021 